\title{
GM FOODS, POWER, AND GLOBALIZATION IN ORYX AND CRAKE
}

\author{
Chao Xie \\ Zhejiang Gongshang University \\ chaoxie1987@126.com
}

\begin{abstract}
Food is taking on a new character in the twenty-first century; it has transformed into a rich site that brings together discussions about race, species, subjectivities, environment, and so on. In the era of the Anthropocene, when human activities have exerted a decisive and unprecedented impact on the earth, the role that food plays deserves closer examination. This article examines genetically modified (GM) food in Margaret Atwood's Oryx and Crake through close reading and looks at how GM food transforms into a global actant that influences nature and culture on a global scale. Investigating the transformation of GM food in the novel, this article argues that GM food raises important questions on issues about power, race, gender, and nation, and becomes a crucial semiotics of environmental ethics in the Anthropocene time.
\end{abstract}

\section{Keywords}

activism; ecocriticism; ecophobia; food justice; posthumanism; realistic relevance

\section{About the Author}

Dr. Chao Xie is a lecturer in the School of Foreign Languages at Zhejiang Gongshang University. His interests include British poetry, animal studies, and ecocriticism. His article "An Analysis of the Animal Images in Mansfield Park" appeared on Journal of Poyang Lake, one of the important journals on ecocriticism in China. His article, "Narrating Animal Suffering in Ye Guangqin's Animal Stories," is forthcoming in the journal $C L C W e b$. Xie is currently working on a project on the climate writings in contemporary British poetry. 
Food is central to Margaret Atwood's Oryx and Crake $e^{1}$ where genetically modified foods (or GM foods), such as the pigoons and ChickieNobs, are transformed foods that challenge traditional ideas about the very nature of food. The result is a series of identity crises and disruptions of hierarchies in the novel. Drawing on the Indian environmentalist Vandana Shiva's theories on food and neo-colonialism, this article uncovers the complicit relationship between technology and globalization, revealing how GM foods is transformed into a global actant that initiates and intensifies social and ecological disasters. By analyzing the transformation of GM foods in the novel, it is clear that GM foods in Oryx and Crake function as a crucial semiotics of environmental ethics which foregrounds issues of power, race, gender, and nation.

The study of food, or what ecocritic Timothy Morton calls "diet studies" (257), has recently gained attention in humanities research, ${ }^{2}$ but little attention has yet been paid to GM foods or how they have transformed traditional foods in terms of both form and meaning. In the Anthropocene, when human activities have exerted decisive impact on the earth, the implication of GM foods and the extent to which they can affect our economics, politics, and environment, deserve a closer look. In the article "The Anthropocene: Conceptual and Historical Perspectives," Will Steffen, Jacques Grinevald, Paul Crutzen, and John McNeill propose that the accelerating drive to understand the genetic basis and to create new forms of life is one of the most controversial twists of the Anthropocene (855). ${ }^{3}$ With this comment, they imply that GM technology neither slows biodiversity depletion nor increases food production; on the contrary, it causes a variety of ecological and social problems. As Oryx and Crake shows, GM foods have transformed into a force that consistently calls human dominance over nature into question.

Oryx and Crake takes GM technology as its main theme and depicts some genespliced animals, which significantly transform traditional definitions of food. By splicing out different parts of organisms to create the pigoons and ChickieNobs, the scientists in the novel create new foods-an act which makes them "feel like god" (57). Different from traditional meat, the pigoons enter the human food chain as medical by-products, since the animals were initially raised to grow human organs for the purpose of xenotransplantation-or the transplantation of living cells or organs from one species to another. The concept of ChickieNobs reduces animals to fast-growing protein producers, turning chickens into tube-like warts. ChickieNobs are something similar to what food theorist and activist Michael Pollan calls "food-like substances" (1): they taste like food but are artificially processed and are not good for human health.

In the discussion of Oryx and Crake in her article "Real-Artificial: Tissuecultured Meat, Genetically Modified Farm Animals, and Fictions," Susan McHugh 
calls the meat produced from the pigoons and ChickieNobs, "real artificial meat." This seemingly oxymoronic term refers to the meat that is produced in "a Petri dish, rather than in whole-animal form" (186). As animal hosts from which the "real artificial meat" is produced are not real animals, this sort of meat transforms traditional ideas towards meat and prompts us to reevaluate our ethical obligations to animals. Producing meat without animals makes the animal absent and obsolete, an extension of the absent referent concept. ${ }^{4}$ Different from normal chicken, ChickieNobs have no brain functions, and the animal welfare issue seems entirely transformed-indeed, absent. GM food becomes an indicator here of the power of biotechnology. As the cases of the pigoons and ChickieNobs illustrate, GM foods have transformed meat beyond animal flesh, turning it into a thing that can be artificially created and programed for both commercial and ethical purposes. The "real artificial meat" here not only disassociates meat from its original meaning, but also problematizes identities of people who consume the meat.

GM foods in the novel call human identity into question by triggering the fear of cannibalism. The protagonist Jimmy (also known as Snowman) is upset about the idea of eating the pigoons. When the OrganInc staff joke with Jimmy and urge him to eat the "pigoon pie," Jimmy is ill at ease, for he thinks of the pigoons with human organs are "creatures much like himself" (27); eating a pigoon, therefore, is like eating a human. Here the pigoons evoke the issue of cannibalism, as the gene-spliced animal blurs the boundary between food and taboo. According to Kristen Guest, the idea of cannibalism triggers "a visceral reaction among people precisely because it activates our horror of consuming others like ourselves” (3). For Jimmy, eating a pigoon that has human organs provokes horror and disgust, as the behavior involves consuming human flesh which is ethically prohibited. The GM food here demonstrates a force that problematizes human identity by destabilizing boundaries between eating and being eaten, human and animal, and self and other. Also, the horror and disgust Jimmy feels bring home the ethical question of eating GM foods, a question that is increasingly becoming central to the studies of environmentalism.

Both the pigoons and ChickieNobs are evidence of what Simon Estok has called "ecophobia" - "an irrational and groundless hatred of the natural world" ("Theorizing" 208). According to Estok, human control of the natural environment implies ecophobia, which "is rooted in and dependent on anthropocentric arrogance and speciesism" (216). GMO foods, where food becomes predictable, less diversified, and easier to control, are good examples of ecophobia. By modifying genetic structures, humans have brought animals and plants under control. Ecophobia is clearly revealed in an environmental ethics wherein mastering nature is unquestioned. The control of the natural environment not only evinces human dominance over nature but also produces unpredictable effects. As Estok aptly puts it, "the more 
control we seem to have over the natural environment, the less we actually have" (208). The fact that in the novel no one can be sure that the pork they consume is not from the human-like animal indicates the hidden power of the pigoons that may turn humans into unwitting cannibals. After surveying the cultural history of food safety and policy in the West, Madeleine Ferrieres maintains that the quality and availability of food have almost always caused fears and anxieties. The pigoons and ChickieNobs are typical cases of food fears, as they shift from being known to being unknown. In other words, the GM food has transformed into a potential symbol of fear and anxiety because it induces ethical taboos and identity crises (Ferrieres 2).

GM foods in Oryx and Crake not only bring about identity crises but also transform into a destructive force that disrupts established power relations. In the discussion about the culture of food, scholars such as Alison Hope Alkon, Julian Agyeman, and Mary Douglas suggest that food is deeply intertwined with personal and cultural identities (Alkon and Agyeman 10; Douglas 67). That is to say, food is an index of power oppositions, and what humans eat reveals their social and class status.

Oryx and Crake features a world characterized by sharp oppositions, one of which is between the sciences and the arts. The protagonist Crake deals with science and enjoys "real shrimps" and "real chicken," whereas Jimmy deals with the arts and has food that is "mostly beige and look[s] like rakunk shit" (218). Initially, science guarantees high-quality food, and those who deal with science enjoy better food. But the established power apparatus is later profoundly challenged by GM foods. The Crakers, the new hominid created by Crake, are programmed to be vegetarians and to feed on grass, leaves, and special caecotrophs. ${ }^{5}$ As Crake explains, this food program simulates their ancestral diet that is higher in roughage, and eaters have to feed on their excrement for extra nutrients. GM technology does not bring a correspondingly high quality food here; rather, it has degraded the quality of the food that the Crakers eat. Similarly, the future of GM food to be consumed by humans also calls technology into question. The artists in the pleeblands give Jimmy a picture of how humans will eat and live in the future when the ozone and oxygen layers are destroyed:

People would creep along through this tubing, single file, stark naked, their only view the asshole of the one before them in the line, their urine and excrement flowing down through vents in the floor, until they were randomly selected by a digitalized mechanism, at which point they would be sucked into a side tunnel, group up, and fed to the others through a series of nipple-shaped appendages on the inside of the tube. The system would be self-sustaining and perpetual, and would serve everybody right. (285-286)

Kritika Kultura 33/34 (2019/2020): 603-617

(c) Ateneo de Manila University

<http://journals.ateneo.edu/ojs/kk/> 
Here, the issues of high technology, eating, and cannibalism are intertwined. Instead of evoking horror as the pigoons do, the man-eating practice carries a sardonic and satiric undertone. Atwood postulates that an effective way to solve the food shortage in the future is to consume human flesh. ${ }^{6}$ Clearly, the GM foods for the Crakers (and for humans in the future) transforms into a deconstructive force that destabilizes the central role of biotechnology. The advanced GM technology, as the writer implies, will not ensure high-quality food for humans in the future; instead, it creates caecotrophy (shit-eating) and cannibalism, which are sensually repulsive and morally unacceptable.

GM foods in the novel also disturb the normal food chain, subverting the binary oppositions between eating and being eaten, and between humans and animals. In the novel, GM foods greatly disrupt the boundary between humans and animals, throwing humans into a posthuman stage. Although critics cannot reach a consensus on the definition of posthumanism, at its core it challenges the deep-rooted concept of anthropocentrism, which puts humans in the center of the natural world. Donna Haraway and Cary Wolfe both point out the power of posthumanism, of which the porous human-animal distinction is an integral part, in deconstructing anthropocentrism (Haraway 151; Wolfe xix). In breaking down the human-animal distinction, posthumanism helps humans make sense of our flexible and multiple identities.

While reading the pigoons in Oryx and Crake, the ecocritic Chung-Hao Ku maintains that Jimmy's grip of power and his identity as a human are profoundly challenged by the gene-spliced animals. $\mathrm{Ku}$ is correct in pointing out that Jimmy's lofty human status fades away, and the protagonist becomes a monster in comparison with the man-made creatures, which have human intelligence (111). However, Jimmy's identity transformation is mostly due to the disruption of the relationship of eating and being eaten. In the post-epidemic world of the novel, the pigoons-which are tacitly regarded as the potential source of meat in the first place-transform into deadly predators that hunt people, viewing Jimmy as "a delicious meat pie" (314). In order to survive, Jimmy always has to watch out for the pigoons that are running everywhere to hunt for humans. The GM food here transforms into a matter that is fully capable of initiating actions, just like human beings. The GM food displays a force that challenges anthropocentrism by tearing down the boundary between humans and animals and between predator and prey. In order to fully demonstrate the agential force of GM foods in the novel, Atwood examines GM foods in the context of modern capitalistic globalization.

GM foods have transformed into a global actant that initiates and intensifies planetary social and ecological disasters in the novel. ${ }^{7}$ GM food is closely related to globalization. The design, production, transportation, and consumption of GM 
food, more often than not, involve international participation. Detrimental effects caused by GM food, such as genetic pollution and social riots, therefore, can be greatly affected in the context of the capitalistic globalization. Oryx and Crake is a novel that consistently features GM food in the context of global capitalistic agribusiness. However, in the current scholarship on Oryx and Crake, the theme of globalization has largely been overlooked. ${ }^{8}$

In many ways, GM foods in Oryx and Crake illustrate the ideas of "ecocosmopolitanism" and "ecophobia" by displaying agential forces in the context of capitalistic globalization. ${ }^{9}$ Globalization has amplified the power of GM foods in the novel. In addition to the pigoons and ChickieNobs, which have successfully created a global market in the novel, Happicuppa reveals the enhanced agency of GM food in which globalization plays a catalyzing role. Developed by a HelthWyzer subsidiary, the GM coffee Happicuppa enables all its beans to ripen simultaneously so that they can be harvested with machines which will ultimately bring down cost and increase profit. Due to its lucrative prospect, Happicuppa is promoted globally. However, this causes worldwide protests because it puts small local growers out of business, pushing them to "starvation-level poverty" (210). As a result, looting and massacre run rampant in many countries, causing economic and political upheavals on a global scale. The case of Happicuppa indicates that globalization has exacerbated the detrimental effects caused by GM foods. ${ }^{10} \mathrm{GM}$ food has transformed into an actant that initiates actions on a planetary scale.

In order to further explore the connections between food agency and globalization embedded in Happicuppa, along with the detrimental effects resulting from it, it is useful that we refer to the Indian environmentalist Vandana Shiva and her ideas on modern agriculture about implications of globalization and genetic engineering for the Global South. According to Shiva, development pursued in the name of economic globalization is a bio-imperialism, and ecological degradation is "a major environmental and social subsidy to global trade and commerce" ("Ecological Balance" 55). In her view, globalization is not "a process of ever widening circles of inclusion," but a process of the concentration of power, a process led by the dominant interests of society, particularly transnational corporations ("Economic Globalization" 22). In her books Biopiracy (1998) and Stolen Harvest (200o), Shiva uses the concepts of "terminator technology," "monoculture," and "patent monopoly" to question high-tech global agribusiness. By promoting one-dimensional monoculture, Shiva says, biotechnologies produce crops "based on a theft of food from other species and the rural poor in the Third World" (Stolen Harvest 12). That is to say, instead of producing more food, biotechnology, colluding with global corporations, creates food insecurity and starvation. The complicit relationship between technology and international corporations, Shiva discloses, here is highly relevant to the case of Happicuppa coffee. 
By promoting the GM coffee worldwide, multinational corporations in the novel make maximum profit at the expense of the environment and small farmers, particularly those in the Global South who are more vulnerable to the impacts of the monocropping. The global planting of Happicuppa coffee incurs infestations and political oppression. The novel mentions that the coffee is menaced by a new bean weevil which is found "resistant to all known pesticides" (253). This is a typical example of genetic pollution, as the monoculture has destroyed biodiversity and given birth to the so-called "superbug." The appearance of the new bean weevil also implies that monocrops may lead to food insecurity which will make the livelihoods of local farmers more difficult. Moreover, national elites also participate in the lucrative global coffee trade in the novel. In order to make room for Happicuppa plantations, the armies not only use nuclear power to clear cloud forests (tropical forests characterized by a frequent low-level cloud cover) but also use violence to kill protesting peasants. Atwood here portrays a riot initiated by food, a riot which illustrates "food totalitarianism," a term Shiva uses to indicate that global food production is increasingly dominated by transnational corporations (Stolen Harvest 17). This shows that GM foods such as Happicuppa have transformed into an actant that intensifies environmental degradation and widens the gap between the North and the South.

Nevertheless, the social and ecological disasters caused by Happicuppa in the novel impact transnational corporations and local peasants to different degrees. The HelthWyzer company takes the global riot triggered by Happicuppa for granted and downplays it as a "usual uproar" (212). For the designers and traders of the GM coffee, the global protest can be controlled, and they can still make money out of it. However, those who grow the coffee in the Global South bear the brunt of the food riot, as many of them lose their local habitats and lives. This uneven influence of GM foods not only reflects how both social and ecological disasters resulting from Happicuppa can be intensified globally, but also embodies unequal social and economic forces in a broader sense.

In fact, the GM coffee not only indicates unbalanced development on a global scale but also gives rise to the issue of food justice. Although much attention has been devoted to environmental justice recently, how environmental justice and food justice are intertwined remains a largely uncharted territory. Environmental justice, as Joni Adamson proposes, "attempts to redress the disproportionate incidence of environmental contamination in communities of the poor and/or communities of color [...] and to afford equal access to natural resources that sustain life and culture" (4). Environmental justice has to do with politics, economics, and race. According to the organization "Just Food" (2010), food justice refers to communities" right "to grow, sell, and eat [food that is] fresh, nutritious, affordable, culturally appropriate, and grown locally with care for the well-being of the land, 
workers, and animals" (Alkon and Agyeman 5). Essential to this definition of food justice is the recognition of the influences of race and class on food production, distribution, and consumption. The planting of Happicuppa, which represents the power of global capitalism, has denied the access of local peasants, especially those in the Global South, to produce natural food and to define their own agricultural systems. In the meantime, the deprivation of the local peasants to food sovereignty exposes the peasants to a higher incidence of environmental degradation and contamination, which are each closely related both to issues of environmental justice and gender politics - a situation clearly depicted in Oryx and Crake.

The alliance between GM food and globalization finds expression in the novel through the female protagonist Oryx. Originally from a poverty-stricken Asian country that has witnessed crop failure due to global warming and climate change, Oryx is forced to go to many developed countries where people can enjoy adequate and better food. Food has been transformed into a driving force for Oryx. When Oryx first tells Jimmy of her childhood experience, she is eating all the way, and her good appetite borders on gluttony. By possessing and consuming all kinds of GM food, Oryx is eager to reclaim power over her own diet, and by extension, over her own life. In order to have better food, Oryx becomes an actress in a porn company in the US, and her porn films are viewed worldwide through the Internet. Like GM food, Oryx's body becomes a commodity on the global market. Shiva notes that the bodies of women and those of plants and animals are "the last colonies" of capitalistic patriarchy (Biopiracy 45). This means that women's sexual and regenerative capacities, analogous to the inner structures of animals and plants, are each targets of colonization. Like the pigoons, ChickieNobs, and Happicuppa, which are genetically manipulated by the capitalist patriarchy, Oryx is exploited sexually on a global scale. Seen in this light, globalization has clustered animals, plants, and women as a group of suppressed others, each closely associated with food. Atwood here pushes us to think through the intersections among neocolonialism, feminism, and environmentalism. More importantly, the author reveals how and to what extent GM food, with the help of globalization, exercises formative power over "others" in the Global South.

The transformation of GM foods in the novel is relevant because the ecological and social problems it has caused in the novel are also evident outside of it. In her essay "Writing Oryx and Crake", Atwood calls the novel "speculative fiction" rather than "science fiction," as she explains, "it invents nothing we haven't already invented or started to invent" (Writing with Intent 285). What the novelist implies is that Oryx and Crake is not built on rootless imagination but rather has a realistic dimension and therefore should be read as a prescient work. Indeed, it is not difficult to find equivalents of the pigoons, ChickieNobs, 
and Happicuppa coffee in our own world. Genetically engineered pigs used for xenotransplantation - the real-life counterpart of the pigoons-are currently being developed. American researchers have succeeded in creating pig-human embryos in 2017, with the hope of one day growing human organs in the animal (Kirkey, "U.S. Scientists"). However, this pig organ transplantation sparked fears because scientific evidence has yet to confirm that potential diseases will not transfer from the animal to humans. Also, animal welfare and ethical issues further complicate the clinical trial of xenotransplantation. What if the genetically modified pigs have human consciousness? What if the meat of the pig ends up on our tables? These questions should be carefully considered before further research is carried on.

In addition, questions about food monopoly and social unrest initiated by GM foods frequently hit mainstream media. Seed companies such as Monsanto have triggered worldwide controversies as they monopolize food by altering the inner structures of plants in order to force farmers to buy their products. By doing so, they have caused ecological and social disasters around the planet. The truth is that GM plants, which were meant to resist pesticides and herbicides, have just the opposite effect, as farmers have to use specific herbicides (such as Roundup, also a Monsanto product) created by the GM companies on the "resistant" crops and weeds. "Superweeds" have become immune to herbicides, just like the new pesticide-resistant bean weevil in the novel. Analogous to the global unrest and riots caused by Happicuppa, millions of people concerned about health and food security have taken to streets recently to protest against GM foods. ${ }^{11}$ To add insult to injury, GM foods pose a grave threat to long-term food security, the natural environment, and social justice, representing a slow violence-"a violence of delayed destruction that is dispersed across time and space" (Nixon 2). As The Guardian reported in 2013, the top six agrochemical firms (including Monsanto) controlled $63 \%$ of the commercial seed market and $75 \%$ of the agrochemical market (Clapp, "Monsanto, Dow, Syngenta").

The centralization and monopoly of food production and distribution by transnational enterprises are bound to put local livelihoods at risk in the long run, as people, especially those from the Global South, now have little control in choosing seeds and plants. Moreover, the loss of biodiversity caused by monocropping will affect global food security in unexpected ways. For instance, large-scale monoculture farming is now a major contributor to climate change, which will in turn incur serious crop failures. All these facts foreground the agency of GM foods and point to a tunnel hidden behind Oryx and Crake which connects the fictional and real worlds. In envisioning a distant future that bears witness to ecological and social degradation where GM foods play a pivotal role, Atwood uses the speculative 
power of fiction to reflect on the decisive and unprecedented impacts of humans on nature.

Oryx and Crake depicts the transformation of GM foods to create an impetus towards understanding the environment. Compared with environmental advocacy groups such as "Earth First!", which are direct in their activist roles, literature cannot save the earth in a direct way, but it can enhance our moral and environmental imagination by calling our attention to the urgency of environmental issues. As a writer who shows sustained concern about environmental issues, Atwood stresses that literature "does not float above the material world in some aesthetic ether but rather, plays a part in an immensely complex global system in which energy, matter and ideas interact" (qtd. in Bhalla, Bhangu, and Singh 771). With this comment, the writer implies that literature is not purely aesthetic but can reflect and influence the natural environment on a global scale. Modern literature which centers on food, as Allison Carruth notes, is "a vehicle attuned to the modern food system due to the capacity of imaginative texts to shuttle between social and interpersonal registers and between symbolic and embodied expressions of power" (5). What Carruth implies is that modern literature on food punctures the boundary between fiction and reality and provides a new insight into environmental ethics. By creating GM foods, humans demonstrate agencies that fundamentally change the natural environment. However, as Jedediah Purdy forcefully notes in a discussion about the Anthropocene, "the more we understand and the more our power increases, the more our control over nature seems a precarious fantasy" (7). The transformation of GM foods as well as the social and ecological disasters incurred by GM foods in the novel prompts readers to reflect on the limits of human agency in the Anthropocene. What Atwood means to convey in the novel, to use her own words, is a set of "what if" questions: "What if we continue down the road we're already on? How slippery is the slope? What are our saving graces? Who's got the will to stop us?' (Writing with Intent 286, emphasis in the original). By using metaphorical language here, Atwood is cautionary. She warns us that human agency is by no means purely intentional but is constrained and shaped by nonhuman nature and is always enmeshed with ecological materialities. This interconnected materialdiscursive configuration greatly challenges dualistic subject-object epistemological structures, for it shows that human dominance over nature is both false and dangerous.

GM foods in Oryx and Crake have transformed into a force that consistently questions traditional definitions of food, human identities, and established power relations. GM foods also transform into a global actant that initiates and intensifies social and ecological disasters on a planetary scale. Through these transformations, GM foods in the novel function as a semiotics of environmental ethics that foregrounds issues of power, race, gender, and nation. By depicting the 
hotly discussed topic of GM foods, Oryx and Crake demonstrates how literature can actively engage with current environmental realities. The transformation, as well as environmental implications, of GM foods in the novel convey the important message that a thing as banal as food is a matter to be reckoned with in our Anthropocene era. 


\section{Acknowledgement}

I want to express my deep gratitude to Professor Simon Estok for his encouragement, patience, and expertise, which are of significant help in revising the article. 


\section{Notes}

1. Atwood shows sustained interest in food. The Edible Woman (1969), Lady Oracle (1976), and The Handmaid's Tale (1985), all bring food, eating, and hunger to the forefront. In 1987, Atwood compiled and illustrated The Canlit Foodbook: From Pen to Plate - a Collection of Tasty Literary Fare, a cookbook based on literary narratives about food. In 2010, the writer helped create a bird-friendly coffee ("Atwood blend") to raise funds and awareness for Canada's Pelee Island Bird Observatory (PIBO). Even though critics have analyzed Oryx and Crake from varied perspectives, such as satire, postcolonialism, and climate change (Bouson; Huang; Botta), GM food, which plays a pivotal role in the novel, has regrettably not been deeply explored.

2. Food has become a hotly discussed topic in humanities studies in the new millennium, and many critics have examined the topic from varied angles. Roland Barthes notes that food can transcend its materiality and is "a system of communication" (24). Taking in Barthes' idea about food, Allison Carruth considers the polysemia of food as "a constitutive feature of modernity" (4). The ecofeminist Carol Adams argues that the way we choose food is always political, cultural, and ecological (Neither Man Nor Beast 123). Jane Bennett maintains that matters such as food and metal are neither passive nor inert; rather, they have agentic capacities, the power to affect and create effects. Food not only enters the process of digestion and metabolism, but also shapes human cognition, intentions, and moral sensibility (51). Many literary journals have published special clusters or issues on food, discussing the relationship between food and culture. For example, Simon Estok edited a special cluster called "Ecocritical Approaches to Food and Literature in East Asia" for Interdisciplinary Studies in Literature and Environment in 2012. For a general picture of the development of the scholarship in food studies, see Carole Counihan and Penny Van Esterik, "Why Food? Why Culture? Why Now?"

3. Will Steffen, Jacques Grinevald, Paul Crutzen, and John McNeill maintain that the Anthropocene began with the Industrial Revolution around 1800 and entered the phase of "the Great Acceleration" after the World War II $(842,849)$.

4. Carol Adams uses the idea of the "absent referent" to indicate the paradoxical condition of both the presence and absence of animals. The term functions to disconnect "meat" from any idea that it was once an animal; meat, therefore, has become "unanchored by its original referent (the animal)," turning into a freefloating image" (The Sexual Politics 13).

5. According to Crake, "caecotrophs" are foods that consist of semi-digested herbage discharged from the anus. Crake explains that caecotrophs is inspired by the food of Leporidae, which can help break down the cellulose and ensure the intake of vitamins.

6. The idea is reminiscent of Jonathan Swift's modest (and satirical) proposal to cook and eat children to solve the Irish population issues. Oryx and Crake alludes not

Kritika Kultura 33/34 (2019/2020): 612-617

(C) Ateneo de Manila University

<http://journals.ateneo.edu/ojs/kk/> 
only to Swift's "A Modest Proposal" but also to Gulliver's Travels (1726). Similar to Gulliver, Jimmy is a castaway figure. The idea of food provision by another group of species (the Crakers provide Jimmy fish once a week) is analogous to the Lilliputians' preparation of food for Gulliver. The Swiftian epigraph at the beginning of Oryx and Crake also testifies to Atwood's literary nod to Swift.

7. I adopt Bruno Latour's definition of "actant," which refers to "something that acts or to which activity is granted by others" (370). According to Latour, an actant is a source of action that can be either human or nonhuman.

8. Only a few critics have touched upon the theme of globalization in the novel. See Peter I-min Huang. "Virtuality, Globalization, and Neo-Primitivism in Margaret Atwood's Oryx and Crake." Foreign Literature Studies, vol. 33, no. 2, 2011, pp. 7-17.

9. Drawing on the risk theory of the German sociologist Ulrich Beck, Ursula Heise poses in her book Sense of Place and Sense of Planet (2008) the concept of "ecocosmopolitanism," which refers to "new, transnational communities arising from shared risk experiences" (123). Estok calls for the theorizing of ecophobia as a way to engage with nature as a global actor in understanding human and non-human nature relationships. GM technology, the "looting and plundering of animal and nonanimal resources" ("Theorizing" 208), to borrow Estok's words, is a typical example of ecophobia.

10. The devastating effects on the Global South caused by the GM coffee is true outside the novel. Over the past two decades, around 30o,ooo farmers took their lives in India (Philpott). Huge media coverage including The Daily Mail and The Independent attribute the majority of these famer-suicides to GM crops (Malone; Lean). Transnational seed corporations such as Monsanto have transformed the traditional farm-saved seeds to corporate seeds which require fertilizers and pesticides. This seed monopoly in India leads to indebtedness, poverty, and finally, suicides.

11. The grassroots movement, "The March against Monsanto," founded in 2013, aims to boycott the products of Monsanto. Tens of thousands of people protested against Monsanto and GM crops in more than 40 countries in May 2015. One year later, people from over 40 countries marched in the streets to express their anger over the merger between Monsanto and the German drug giant Bayer, which resulted in the creation of the world's largest supplier of farm chemicals and GM seeds. 


\section{Works Cited}

Adams, Carol J. Neither Man Nor Beast: Feminism and the Defense of Animals. Continuum, 1995.

-.. The Sexual Politics of Meat: A Feminist-Vegetarian Critical Theory. Continuum, 2010.

Adamson, Joni, Mei Mei Evans, and Rachel Stein. The Environmental Justice Reader: Politics, Poetics \& Pedagogy. U of Arizona P, 2002.

Alkon, Alison Hope, and Julian Agyeman. "Introduction: The Food Movement as Polyculture." Cultivating Food Justice: Race, Class, and Sustainability, edited by Alison Hope Alkon and Julian Agyeman, The MIT P, 2011, pp. 1-20.

Atwood, Margaret. Oryx and Crake. Virago, 2003.

-.. Writing with Intent: Essays, Reviews, Personal Prose, 1983-2005. Carroll \& Graf Publishers, 2005.

Barthes, Roland. "Towards a Psychosociology of Contemporary Food Consumption." Food and Culture: A Reader, edited by Carole Counihan and Penny Van Esterik, Routledge, 2008, pp. 23-30.

Bennett, Jane. Vibrant Matter: A Political Ecology of Things. Duke UP, 2010.

Bhalla, Ambika, Jap Preet Kaur Bhangu, and Manmohan Singh. "Margaret Atwood's Oryx and Crake: An Ecocritical Approach." International Journal of Research, vol. 1, no. 10, 2014, pp. 765-773.

Botta, Giuseppina. "Faustian Dreams and Apocalypse in Margaret Atwood's Oryx and Crake." Local Natures, Global Responsibilities: Ecocritical Perspectives on the New English Literatures, edited by Laurenz Volkmann, Nancy Grimm, Ines Detmers, and Katrin Thomson, Rodopi, 2010, pp. 243-256.

Bouson, J. Brooks. 'It's Game Over Forever': Atwood's Satiric Vision of a Bioengineered Posthuman Future in Oryx and Crake." Bloom's Modern Critical Views: Margaret Atwood, edited by Harold Bloom, Infobase Publishing, 2009, pp. 93-110.

Carruth, Allison. Global Appetites: American Power and the Literature of Food. Cambridge UP, 2013.

Clapp, Jennifer. "Monsanto, Dow, Syngenta: Rush for mega-mergers puts food security at risk." The Guardian, 5 May 2016, www.theguardian.com/sustainable-business/2016/ may/o5/monsanto-dow-syngenta-rush-for-mega-mergers-puts-food-security-at-risk. Accessed 1 Oct. 2017.

Counihan, Carole, and Penny Van Esterik. "Why Food? Why Culture? Why Now?" Food and Culture: A Reader, edited by Carole Counihan and Penny Van Esterik, Routledge, 2013, pp. 1-18.

Crutzen, Paul, and Eugene Stoermer. “The Anthropocene." IGBP Newsletter, no. 41, 2000, pp. 17-18.

Douglas, Mary. Purity and Danger: An Analysis of the Concepts of Pollution and Taboo. Routledge, 1996. 
Estok, Simon C. "An Introduction to 'Ecocritical Approaches to Food and Literature in East Asia': The Special Cluster." Interdisciplinary Studies in Literature and Environment, vol. 19, no. 4, 2012, pp. 681-690.

--. "Theorizing in a Space of Ambivalent Openness: Ecocriticism and Ecophobia." Interdisciplinary Studies in Literature and Environment, vol. 19, no. 2, 2012, pp. 203-225.

Ferrieres, Madeleine. Sacred Cow, Mad Cow: A History of Food Fears. Columbia UP, 2005.

Guest, Kristen. "Introduction: Cannibalism and the Boundaries of Identity." Eating their Words: Cannibalism and the Boundaries of Cultural Identity, edited by Kristen Guest, State U of New York P, 2001, pp. 1-9.

Haraway, Donna. Simians, Cyborgs, and Women: The Reinvention of Nature. Routledge, 1991.

Heise, Ursula. Sense of Place and Sense of Planet. Oxford UP, 2008.

Huang, Peter I-min. "Virtuality, Globalization, and Neo-Primitivism in Margaret Atwood's Oryx and Crake." Foreign Literature Studies, vol. 33, no. 2, 2011, pp. 7-17.

Kirkey, Sharon. "U. S. scientists create human-pig chimera embryos to grow human cells: 'This requires a tour de force." National Post, 26 Jan. 2017, www.news.nationalpost. com/health/u-s-scientists-create-human-pig-chimera-embryos-to-grow-human-cells. Accessed 1 Oct. 2017.

$\mathrm{Ku}$, Chung-hao. "Of Monster and Man: Transgenics and Transgression in Margaret Atwood's Oryx and Crake." Concentric: Literary and Cultural Studies, vol. 32, no. 1, 2006, pp. 107-133.

Latour, Bruno. "On Actor-Network Theory: A Few Clarifications." Soziale Welt, vol. 47, no. 4, 1996, pp. 369-381.

Lean, Geoffrey. "Charles: 'I blame GM crops for farmers' suicides." The Independent, 5 Oct. 2008, www.independent.co.uk/environment/green-living/charles-i-blame-gm-cropsfor-farmers-suicides-951807.html. Accessed 7 Oct. 2018.

Malone, Andrew. "The GM genocide: thousands of Indian farmers are committing suicide after using genetically modified crops." Mail Online, 3 Nov. 2008, https://www. dailymail.co.uk/news/article-1082559/The-GM-genocide-Thousands-Indian-farmerscommitting-suicide-using-genetically-modified-crops.html. Accessed 7 Oct. 2018.

McHugh, Susan. "Real-Artificial: Tissue-cultured Meat, Genetically Modified Farm Animals, and Fictions." Configurations, vol. 18, no. 1, 2010, pp. 181-197.

Morton, Timothy, "Let Them Eat Romanticism: Materialism, Ideology, and Diet Studies." Cultures of Taste/Theories of Appetite: Eating Romanticism, edited by Timothy Morton, Palgrave, 2004, pp. 257-277.

Nixon, Rob. Slow Violence and the Environmentalism of the Poor. Harvard UP, 2011.

Philpott, Tom. "No, GMOs didn't create India's farmer suicide problem, but..." Mother Jones, 30 Sept. 2015, www.motherjones.com/food/2015/o9/no-gmos-didnt-createindias-farmer-suicide-problem. Accessed 7 Oct. 2018.

Pollan, Michael. In Defense of Food: An Eater's Manifesto. Penguin, 2008.

Purdy, Jedediah. After Nature: A Politics for the Anthropocene. Harvard UP, 2015. Shiva, Vandana. Biopiracy: The Plunder of Nature and Knowledge. Green Books, 1998. 
--. "Ecological Balance in an Era of Globalization." Global Ethics and Environment, edited by Nicholas Low, Routledge, 1999, pp. 47-69.

--. "Economic Globalization, Ecological Feminism and Sustainable Development." Canadian Woman Studies, vol. 17, no. 2, 1997, pp. 22-27.

--. Stolen Harvest: The Hijacking of the Global Food Supply. Zed Books, 2000.

Stephen, Will, Jacques Grinevald, Paul Crutzen, and John McNeill. "The Anthropocene:

Conceptual and Historical Perspectives." Philosophical Transactions of the Royal

Society, vol. A, no. 369, 2011, pp. 842-867.

Wolfe, Cary. What is Posthumanism? U of Minnesota P, 2010.

Kritika Kultura 33/34 (2019/2020): 616-617

(c) Ateneo de Manila University 